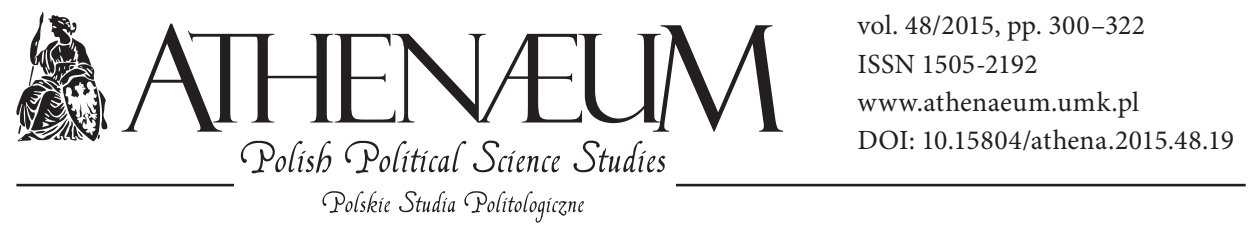

\title{
THE SELECTED ISSUES OF THE ESTABLISHMENT OF THE EUROPEAN PARLIAMENT AS AN INSTITUTION OF THE EUROPEAN UNION AND THE EVOLUTION OF THE ELECTORAL LAW SINCE ITS INCEPTION UNTIL NOW
}

\author{
Agnieszka Marczyńska*
}

\begin{abstract}
It is without any doubt that one of the most important elements of every democratic political system is a Parliament, that is, a collective authority elected in direct elections, which is simultaneously an emanation of will of citizens as a sovereign. Over the years of the technological development of societies and evolution of the economic cooperation amongst states, its role and scope of responsibilities have gradually grown. The European Parliament is one of the key elements of the institutional system of the European Union, and thus, the only body, the composition of which is elected in direct election. This body, as a forum for universal representation by the elected deputies from the member states, brings together views and positions not only of the representatives but also of their electorate. The parliament is also an expression of the multinational EU community, its voice and its desire to have influence on the fate of the entire EU.

This article presents the evolution of the European Parliament and of the election law concerning this body, since its formation as an institution of the European Union until now. The purpose of this article is to present changes which have taken place in the EU legislation in respect of the electoral law, on the basis of which members of the parliament are elected, since the formation of the EP. The main subject of this article covers following issues: how the evolution process of the parliament has looked like over the years, how its position in the institutional architecture of the EU has been evolving and how it has been endeavoured to harmonize electoral procedures to this body over the years. The article is about the evolutionary political
\end{abstract}

* University of Social Sciences and Humanities in Warsaw, Faculty of Law. 
position of the EP. The article focuses on selected aspects of unification of the electoral procedure for the election to the EP due to their path-breaking character and importance of the procedure being currently in force.

\section{- KEYWORDS}

European Parliament, European Union, election, electoral law

\section{THE ESTABLISHMENT OF THE EUROPEAN PARLIAMENT AS AN INSTITUTION OF THE EUROPEAN UNION}

One of the key bodies of the European Communities is the European Parliament, which has been known under this name since 1962. It is the only experiment of this kind in the field of supranational democracy (Jacobs, Corbett, Shackleton 1996: 16) which reflects the principle that nations should take part in the exercise of power through an assembly representing them (Jacobs, Corbett, Shackleton 1996: 313). The beginnings of formation of the European Parliament model can be found in the Treaty of Paris establishing the European Coal and Steel Community (hereinafter referred to as ECSC) on April $18^{\text {th }}, 1951$ (Europa-Verträge und Gesetze 1972). The first session of the ECSC Assembly took place on September $10^{\text {th }}, 1952$, and was attended by 78 deputies. During negotiations on the adoption of the Treaty, Jean Monet, who was one of the deputies, suggested the establishment of an Interparliamentary Assembly among the existing classic bodies of international organizations, which would consist of parliamentarians of the member states. The Assembly was supposed to have advisory powers and the privilege to express the vote of no confidence to the authority (Klepacki 1967:25). The above-mentioned view, which had reflected the trend towards supranational integration, found its expression in the statutes of the organization. It is believed that the prototype of the European Parliament should be sought in the Consultative Assembly of the Council of Europe, which was established in August 1949 and was the first European parliamentary assembly. However, the efforts to establish a federal bicameral parliament proved to be unsuccessful. Anyway, it seems to be reasonable to mention these efforts, since they are undoubtedly a confirmation of the presence of a developed concept, which was patterned upon national models of a representational institution of parliamentary nature (Kruk 1997: 7). The supporters of the supranational integration saw a future common Western European Parliament in the Assembly (Marszałek-Kawa 2002: 8). 
Under the Treaties of Rome adopted on March $25^{\text {th }}$, 1957, two European Communities were established, namely the European Economic Community (EEC) and the European Atomic Energy Community (hereinafter referred to as Euratom). The Statutes of the two European Communities in institutional terms were patterned upon the ECSC status and sanctioned that every one of the Communities would have the following organs: an International Council of Ministers, a Special Commission, which would act as a managing authority, a Parliamentary Assembly and a Court, which would exercise the judicial authority. While both of the statutes were created, the main assumption was that they would have a joint parliamentary body. However, originally it was not assumed to create such a body for all three communities. As a result of numerous conferences, meetings and discussions, the so-called concept of the joint institutions for the European Communities was created, on the basis of which the joint parliamentary body for the ECSC, EEC, and Euratom was created (Galster 1997: 9-10). The Convention, however, does not include the status of the body mentioned above. It only constitutes that a joint parliamentary body will be established for the three communities (Europa-Verträge 1972: 258-262).

The first session of the joint parliamentary body of all three European Communities took place in Strasbourg on March 19 $9^{\text {th }}, 1958$. It was attended by 148 deputies representing national parliaments of the so-called "Six", i.e. Germany (FRG), Belgium, France, Italy, Luxembourg, and the Netherlands. The joint body was granted consultative-control powers, however, it was characterized by a constant activity in the sphere of customs from the very beginning and it aimed at strengthening its position through consistent increase in its powers (Kruk 1997: 8). Under the Treaties of Rome, the European Parliament had no tools to shape and influence the policies of the member states. It was only the Article 238 of the EC Treaty that entitled EP to consulting association agreements (Czachór 1994: 80). With the resolution of 1959, the Assembly changed its name to the European Parliamentary Assembly. While it was in 1962 that the Assembly adopted the name of the European Parliament. The opponents of the new name, while maintaining their position, were arguing that the Treaties establishing the European Communities did not use the name in their content. Some of the opponents were going further and were questioning the desirability of the appointment of a body of this nature and they negated simultaneously the adopted development direction of the Communities, which, according to them, as a result aimed at establishment of a transnational structure of federal nature 
(Kruk 1997: 8). Legal sanctioning of the name "The European Parliament" took place on the date of adoption of the Single European Act, hereinafter referred to as SEA, i.e., on February $17^{\text {th }}, 1986$, which finally entered into force on July $1^{\text {st }}$, 1987. While strengthening the EP position, the SAE introduced the principle of expression its approval for conclusion of accession agreements with new member states and association agreements by the Communities (MarszałekKawa 2004: 81).

Under the Treaties mentioned above, the members of the Parliamentary Assembly were supposed to be appointed by the parliaments of the Member States. The provisions of the Treaty of Paris of 1951, stating that the Parliamentary Assembly is composed of „[...] representatives of nations united in the Community", introduced two alternative models for appointing members of the Assembly. The first of them provided that representatives of the member states should be elected by national parliaments from their members once a year. The second one provided that representatives should be elected in direct universal suffrage under the conditions adopted by the law of the member states.

The Treaties of Rome went even further; they stipulated that the composition of the assembly would be determined by a direct universal suffrage based on a uniform electoral procedure, which would be in force in all member states (Grzelak 2004: 24). According to the art. 138 of the Treaty: "The Assembly will present proposals on direct universal suffrage according to a uniform procedure in all member states. The Council, acting unanimously, shall establish appropriate procedures, which will be recommended for adoption by the Member States in accordance with their individual constitutional requirements" (Treaty establishing the European Economic Community, signed 25 March 1957, Journal of Laws 2004, No 90 item 864/2). Until creation and adoption of a uniform electoral procedure, the deputies shall be elected by national parliaments. Thus, as it results from the analysis of the Treaty, it was the National Assembly that was responsible for drafting a uniform election law. It was in the period from 1958 to 1975 that the Assembly adopted two resolutions and created two drafts of the uniform electoral law. The working party chaired by Ferdynand Dehousse presented its proposals as first one on May $17^{\text {th }}, 1961$. The draft assumed that $2 / 3$ of the members of the Parliament would be elected by direct universal suffrage and the rest of the deputies would be appointed by the parliaments of the Member States. The European Parliament passed the draft mentioned above to the Council of the European Union, however, it was not subject to discussion due to the many differences of opinion among the member states (Gebethner, 
Urbaniak 2003: 13). The attempts to harmonize and regulate the elections to the European Parliament were undertaken in 1963 and 1969, but they were also unsuccessful. The next attempt to draft a project of the electoral law for the European Parliament was undertaken by Schelto Patijn. It was as a result that in January 1975, the European Parliament passed the draft of the law by a majority of 106 votes, which was signed by the Council of the European Union on July $12^{\text {th }}, 1976$. This proposal contained many articles relating to activities and functioning of the European Parliament, among others, the issue of the term of office. Schelto Patijn, who was already mentioned above, strove for a compromise with the opponents of universal suffrage and creation of a uniform electoral law. The draft of the electoral procedure prepared by him and adopted by the Council assumed that the first elections to the European Parliament should be carried out based on the national, not necessarily uniform procedure, and authorized the newly elected Parliament to create a new electoral procedure in the future. The draft of the electoral law sanctioned also that a deputy should be independent and autonomous in his decisions and the members of the parliament should vote based on their own beliefs. The deputies should not be restricted by any mandate or instructions (Jacobs, Corbett, Shackleton 1996: 41). Until 1979, i.e. the first general election, deputies to the European Parliament had been appointed by national parliaments of the member states from the their national deputies (Kenig-Witkowska, Łazowski, Ostrihansky 2006: 81).

As new member states accessed to the European Communities, the number of the deputies gradually grew. As I have already mentioned above, the number of the deputies in the European Parliament at the moment of its establishment was 142; this number increased to 198 in 1973, when Denmark, Ireland, and the United Kingdom acceded to the European Communities. On the day of first direct universal suffrage, the number of the deputies was already 410. In 1981, after the accession of Greece, the number of the deputies rose to 434 people (Małuszyńska, Gruchman 2010: 4). And so, with every accession of new member states to the European Communities, the number of the deputies in the EP systematically grew and currently amounts 751 deputies.

It is next to the Council of the European Union, which has decision-making and legislative powers, and to the European Commission, which in turn is the EU's executive arm, that the European Parliament has a significant impact on functioning of the European Union. However, at the time of its establishment, as it was shown above, it had not widely developed powers. Its powers were limited mainly to consultative and advisory ones. While from the moment of its 
establishment, it tried successively to extend its impact and gain greater ability to influence the functioning of Communities and policies of the Member States (Apostol 1995: 10). The increase in the powers of the EP compared to other EU bodies is a response not only to their evolution towards closer cooperation, but also towards more comprehensive integration amongst Member States. The increased powers have not offset the phenomenon, which is called "a deficit of the democratic legitimacy" in the European literature (Dinan 1993: 188). This "deficit" is due to the fact that the process of the successive transfer of the legislative powers from the level of the Member States to the EU level is a process of transferring legislative powers from representative bodies elected in democratic elections to the body consisting of the representatives of governments (Council), in which the participation of the representative body, i.e. parliament, is incomparably smaller than in the Member States. The gradual elimination of this deficit of the democratic legitimacy is an essential element for counteracting the process of alienation of citizens from the process of governance of the Union (Ostrihansky 1995: 7). It should also be noted that the EP is a different institution than the existing parliaments in the Member States. There is no ruling majority or opposition in it, it does not have a classic legislative function, it does not have a legislative initiative, it has quite a small role in the legislative act. It also does not perform its duties on behalf of one and the same Member State, since its members are elected by the citizens of all member states (Chmaj, Skrzydło 2011: 119).

\section{WORKS ON STANDARDISATION OF THE ELECTORAL LAW TO THE EUROPEAN PARLIAMENT OVER THE YEARS}

One crucial problem of the electoral law to the European Parliament is a lack of common and uniform regulations related to organisation of elections in Member States. At the community level, there were several attempts to develop a uniform electoral law. The first provisions concerning the electoral procedure to the Joint Assembly of the European Coal and Steel Community were included in the Treaty of Paris of 1951. Provisions of the treaty regulated only the rule of the university and directness of the elections, while ECSC states had a freedom in respect of details of the electoral procedure (Bardi 1990: 503-529). Members of the European Parliament were nominated pursuant to the above mentioned regulations, in some cases accepting common elections (Kownacki 2004: 18). 
The issue of harmonisation of the electoral procedure was considered only in the Treaty of Rome in 1957. According to Art. 138 Par. $3^{1}$, all Community Member States were to implement a uniform electoral law. The first attempt of standardising the matter of uniform electoral law and direct elections to the European Parliament was a submission of a draft of an electoral convention to the parliamentary commission of the European Parliamentary Assembly, which was presided by a Belgian socialist Fernand Dehousse. It took place on May $17^{\text {th }}, 1960$ and the convention was named after the chair's name, i.e. so-called Dehousse's convention (Bieber 1981:21-28.) The draft assumed that the Assembly of 426 members would be nominated in the course of general election, taking place once per five years. However, during a transition period, $2 / 3$ of the Assembly members would be elected directly, i.e. according to the new rules, and the rest would be nominated by national parliaments of member states. The elections in each Community state would take place on the same day. The convention included also regulations concerning the minimal age of eligibility to stand for election, set for 21-25 years, and the incompatibilities rule, i.e. the rule forbidding joining function of a member of the European Parliament and a member of a national parliament. The project authors did not focus much on the common electoral procedure but only stated that during a transition period, the elections would take place as previously in accordance to national procedures. Article 9 of the Convention generally stated that the procedures should be uniform to the highest possible extent. Finally, the Convention by Dehousse was to enter into force after having been ratified by all member states, however, this failed due to an objection of France (Chałupa 2008: 3-4).

The following attempt of harmonising the European Parliament electoral procedure was undertaken when next countries entered the Community, i.e. United Kingdom, Ireland, and Denmark. It took place in 1973, at the time when the president of the Parliament Commission was a Danish social democrat S. Patijn. The Commission was called after its chair - the Patijn Commission. The result of the Commission's works was a convention draft, submitted in January 1975, which was titled Legal act concerning election of members of the Assembly in direct elections. Article 1 of the Act assumed that organisation of direct and general elections to the European Parliament would be based on a uniform electoral law, developed by the European Parliament. However, the Convention did not specify its term (Millar 1990: 37-44). It specified the number of Parliament

\footnotetext{
${ }^{1}$ Art. 190 of the Treaty forming the European Community.
} 
members at 355, the term of office of 5 years and the list of functions which could not be combined with the function of a parliament member, the schedule and general rules of elections.

Parliament members were not to be burdened with instructions of mandates of a state they came from. What is more, the document indicated the criteria allowing candidates to start in the election, however, did not systematise the electoral system, authorising the European Parliament to harmonise it. It was also agreed that the election date would be set authoritatively and would take place in one period. Member states were just obliged to organise elections in one period, covering four consecutive days, from Thursday till Sunday, and that they can start counting votes from the moment of a finish of the election in the last country. Other issues concerning organisation and conduction of the election were within competences of particular member states.

Finally, the Patijn Report was adopted with slight amendments by the European Council in January 1975. The number of members was changed to 410, while the election was to be conducted within four consecutive days, starting from Tuesday till Sunday. Particular elements of the electoral procedure were left within responsibilities of Member States (Jacobs, Corbett, Shackleton 1996: 10). Previously, during the European Council summit in Paris in 1974, there was made the decision that the first election to the European Parliament were to take place as late as in 1978 (Bardi 1990: 520). It should be also mentioned that the first election to the European Parliament finally took place from $7^{\text {th }}$ until $10^{\text {th }}$ June 1979.

On the basis of agreements set in Patijn report, representatives of the Member States agreed on the content of the earlier mentioned Act, concerning election of European Parliament members in direct and general elections during the summit of the European Council, which took place in July 1976. The Act was the first official document of European Communities, including a set of basic rules of EP electoral law for all member states, at the same time being the first step towards harmonising the electoral procedure. Finally, the Act was adopted on September 20 ${ }^{\text {th }}, 1976$ by the Council decision no. 76/787/ECSC. A detailed description of provisions included in the act shall be presented further in this article.

Further defining of a uniform electoral act was continued in the European Parliament when a French member of Christian democracy fraction Jean Seitlinger became the chair of the Commission for politic affairs. He exercised this function in the years 1979-1984, and in October 1980, he presented his 
report. In February 1982, it was adopted by the Commission, and on March $10^{\text {th }}, 1982$, by the Parliament. According to the draft, the European Parliament elections should be based on regulations included in the Act of 1976 and national law of Community states. According to Art. 2 of the draft, all member states would be subject to a proportional electoral system and would be divided into multi-member districts. What is more, that document introduced the D'Hondt method as the system of selecting members (Art. 3, Par. 1), preferential election within a single list, the right to vote and start in elections regardless the place of living, a flexibility in the field of geographical and ethnical condition, a lack of election threshold, as well as a two-day voting period.

However, the presented project was not approved by the European Council. J. Seitlinger considered the fact that it was very difficult to convince European Council members to make more complex amendments in the EP electoral law, thus, he focused on fundamental elements of the electoral system. However, the Council did not decide to introduce changes proposed in the Seitlinger's report before the election in 1984. A lack of a unanimous consent at the level of the Committee of Permanent Representatives resulted from a negative position of the United Kingdom, which was an opponent of introducing a proportional system due to the fact that British electoral law was based on the plurality voting system (Westlake 1994: 77-78).

During the second tenure of the EP, in the years 1984-1989, Reinhold Bocklet, the Rapporteur of the Political Affairs Committee, focused on developing a uniform electoral law. A draft he presented in 1987 assumed an adoption of a proportional system, with single or multi-member districts, creating national voting districts, an introduction of an election threshold of maximum 5\% and the necessity to have a citizenship allowing both voting as well as to be eligible to be elected. The Bocklet report acquired a positive opinion of the EP Political Affairs Committee, which directed it to a detailed development by a working team composed of the members of Political Affairs and Legal Committees. The group was presided by R. Bocklet. In 1986, the group presented a verification, however, similarly as previously discussed projects, it was not presented at a plenary session (Jacobs, Corbett, Shackleton 1996: 64).

During the third EP tenure in the years 1989-1994, the task to prepare a draft of a uniform electoral law was committed to the Institutional Committee, which supervised the Political Affairs Committee, presided by a Belgian liberal Karl de Gucht. He presented an initial version of his report in 1991. It was regarded as flexible. A resolution of the European Parliament, stating that 
a uniform electoral procedure should constitute a general, not detailed formulation, resulted in the fact that the report was adopted on October $10^{\text {th }}, 1991$. The chief aim of the report was specified in Art. a of EP Resolution of October $10^{\text {th }}$ on the European Parliament's guidelines for the draft uniform electoral procedure „[...] acknowledging that the main aim was to lead to harmonising electoral criteria in all member states after twelve years after the first direct election. The European Parliament should immediately adopt the procedure being a widely understood consensus of all Community members. A uniform electoral procedure in all countries would politically enforce the importance of the institution and consolidate its democratic legitimisation in the field of economic and monetary cooperation, aimed at transforming the Community into a body of an European federation..."2.

A catalogue of solutions proposed by Gucht, included in the EP Resolution, contained provisions concerning an introduction of an age census for passive and active voting rights of 18 years. The situation of citizens of other member states staying abroad should be set by internal regulations of a particular member state. Art. $2^{\text {ii }}$ includes an obligation of organising the election within four particularly set days. Another solution proposed in the Resolution, on the basis of Art. 2v, was a prohibition to be at the same time a MEP and to serve a function set in the Act concerning election of the Assembly members in direct and general elections of September $10^{\text {th }}, 1976$, broadening those functions by a district management member. Despite the fact that EP claimed to organise the election basing on the proportional system, due to an objection of the United Kingdom it was decided that "[...] no more than $2 / 3$ of members were elected in accordance to the national system, provided that the rest of them are elected in a way that the proportion between the number of acquired votes and the number of members is kept in the national scale". The Gucht's report in its final version was adopted only in 1993. Next, the report was directed to the Council. At that time, the Community presidency was held by Denmark, which was more focused on the ratification of the Treaty on European Union, what resulted in the fact that the above report became a subject of negotiation only at the end of 1993. When making an opinion on the submitted project, it was stated that it is the least coherent among all previously presented as far as the uniform electoral

2 European Parliament Resolution of October $10^{\text {th }}, 1991$ on the European Parliament's guidelines for the draft uniform electoral procedure, http://www.ena.lu. 
law is concerned. Due to its too general character, it was even said that it is incompatible with Art. 138 of the Treaty on European Union, which authorises the EP to develop projects aimed at enabling an organisation of direct elections basing on an uniform electoral law in all member states.

The following election was organised basing on the rules specified in the Act of 1976 (De Vries 1996: 417-421). The above mentioned Treaty on European Union concluded on February $7^{\text {th }}, 1992$, by the power of its provisions, introduced the rule of EU citizenship. Art. $8^{\mathrm{b}}$ stated that ,each EU citizen living in the area of a member state which he or she is not a citizen of, is has the right to vote and is eligible to be elected to the PE in a member state he or she lives, basing on the same rules as this state's citizens". The Treaty entered into force on November $1^{\text {st }}, 1993^{3}$.

Amsterdam Treaty, enacted on October $2^{\text {nd }}, 1997$, amended the above mentioned Art. 138 Par. 3, stating that it is possible to organise general direct election to the EP in accordance to an uniform procedure or basing on common rules for all member states. This treaty entered into force on May $1^{\text {st }}, 1999^{4}$.

A result of the amendment of Art. 138 Par. 3 was a report of the Institutional Committee of the European Parliament, which in the years 1994-1999 was presided by Georgios Anastassopoulos from Greece. This report specified the election rules, e.g. introduced a 5\% election threshold, an obligatory division into voting districts only in case when the number of citizens of a member state exceeds 20 million. Additionally, the act assumed the rule of not combining the function of a MEP with the function of a national deputy. The report was adopted on July $15^{\text {th }}, 1998$. According to the report, new solutions accepted „[...] a simple and flexible model, while the introduced changes should always consider two superior rules: close cooperation with the electorate and proportion"5.

\footnotetext{
3 Treaty on European Union of February $7^{\text {th }}, 1992$, Journal of Laws C no. 191 of 29.7.1992.

${ }^{4}$ Amsterdam Treaty of October $2^{\text {nd }}, 1997$, Journal of Laws C no. 340 of 10.11.1997.

${ }^{5}$ Introduction, Elections to the European Parliament: 10-11 \& 13 June 1999 Electoral Procedure, Electoral Law, http://www.europarl.europa.eu/election/law/en/lain01en.htm.
} 


\section{COUNCIL DECISION OF SEPTEMBER 20, 1976 \\ NO. 76/787/ECSC, EC, EURATOM AND ITS AMENDMENT BY DECISION NO 2002/772/EC, EURATOM}

A breakthrough in a development of a uniform electoral law took place in 2002, when the Institutional Committee was presided by Jose Maria Gil-Robles y GilDelgado, who was previously a president of the EP. In 2002, during the summit in Nice, the issue of preparing a standardised electoral procedure for the EP was not a subject of proceeding. His report concerned the amendment of the Act of 1976 concerning direct and general election to the EP. His authorship project was adopted on the basis of the consent procedure of June $12^{\text {th }}, 2002$, and was published in the Official Journal of the European Communities on October $21^{\text {st }}, 2002$.

The above mentioned lack of introducing a uniform EP electoral procedure at the Community level makes that specifying the regulations is mainly of the responsibility of member states. The Act of 20.09.1976 includes general rules of organising EP election which were amended in 2002 (Polarczyk 2009: 2).

Pursuant to Article 1, election of the European Parliament members shall take place within the scope of general, direct, free and anonymous election. What is more, according to Par. 1, the election is organised on the basis of the proportion rule, which can evince in a use of allocation of members of the system of party lists or a single vote subject to a transfer. The proportion rule was introduced only when amending the original version of the Act of 1976. The preferential electoral law is characterised by the fact a vote constitutes a list arranged on the basis of voter's preferences. A voter arranges the candidates according to own preferences, e.g. checking all or some of them with number 1 for the best candidates and number 2 for a following one. In this way, he or she creates a so called preferential list. Examples of such solution include e.g. Schulze method or voting with transferable vote method. Single transferable vote system consist in that a voter selects one candidate from the list, at the same time selecting other candidates, which should receive his/her vote when his/her initially selected candidate received enough number of votes or too less number, what makes him/her eliminated. This system is used e.g. in Ireland or in Malta (Bartholdi 2003: 17-23).

Pursuant to Art. 2 of the Council Decision, member states are allowed to form voting districts or to divide a voting area in other way, generally not 
violating the proportional character of the electoral system. Currently, only few countries divide their areas into voting districts and the largest number of them is formed in Poland - 13. Pursuant to Art. 3, one crucial issue which is guaranteed to Community states is the possibility to introduce a minimal election threshold, provided that its maximal value is $5 \%$. Member states are allowed to set an upper limit of expenditures for the electoral campaign (Art. 4). MEP are elected for 5 years tenure, which starts on the day of the first session after the election. The Parliament meets without the necessity of convening it, on the first Tuesday after a month from the end of the electoral period. Competences of the outgoing Parliament end in the moment of the opening of the first meeting of new Parliament. The tenure of each MEP starts and ends in the same term (Art.5). Article 6 includes the guarantee of a freedom of MEP. MEPs cannot be burden with any instructions, nor receive any bounding mandate. Article 7 includes the rule of not combining the MEP function with particular functions. The specification of detailed rules of organising elections is still at the responsibility of particular member states on the basis of national legislation, pursuant to Art. 8. What is more, it is stated that no one is allowed to vote more than one time in particular EP election (Art. 9). Pursuant to Art. 12, EP verifies the mandate of MEPs. It notes results officially announced by member states and settles disputes which can result due to the Council Decisions, other than those resulting from national regulations, to which the Decision does not refer. Article 13 of the Council Decision includes provisions concerning a selection of a member due to a resignation, death, or loss of the mandate by other member. The procedure to select a member in such situation is at responsibility of member states. What is more, member states are authorised to specify cases when a MEP loses the mandate due to national law. If a national legislation includes such provisions, the loss of the mandate is pursuant to such regulation. In such case, proper national authorities inform the European Parliament about such fact. However, in case when the vacancy results from a resignation or death, the EP president immediately informs proper authorities of a Community state about such fact.

The Act of 1976 on direct and general election, amended by the decision of 25.06.2002 and 23.09.2002, is the only amendment concerning a uniform EP electoral procedure so far. After that amendment, there have not been any real attempts of standardising the electoral law. Currently, we still lack such attempts. 


\section{DIRECTIVE NO 93.109/EC OF 06.12.1993}

The right of all EU citizens to vote and start in the EP elections in a state where they have the right to live was acknowledged pursuant to Art. 20 Par. 2 B of the Treaty on European Union (further referred to as TEU), and Art. 39 Par. 1 of the Charter of Fundamental Rights of the European Union. For the aims of realisation of the TEU directives in the scope concerning electoral rights of the EU citizens living in a Community state which he/she is not a citizen of, the Council, on 06.12.1993, issued the Directive no. 93/109/EC stating detailed conditions of passive and active electoral rights in the EP elections for the EU citizens, living in a member state they are not citizens of (Directive no. 93/109/EC of 06.12.1993, Journal of Laws L no. 329 of 30.12.1993: 34). This Directive specifies rules according to which citizens of member states living in a country other than their state of origin have active and passive electoral rights. The directive at its start defines terms used in its content. One of the most crucial definitions states that a Community voter is a voter authorised to vote in a member state when he or she lives, while a person eligible to be elected is an EU citizen eligible to be elected to the EP in a member state of place of living. Directive specifies that an EU citizen who is not a citizen of a member state where he/she lives and meets all other voting and being elected conditions which a state sets for its citizens has an active and passive EP electoral right in a member state where he/she lives. On the other hand, such right is not given to persons who, as a result of a sentence or a decree issued on the basis of a penal or civil law of a member state, whether of living or origin, were deprived of the law to start in the election. However, if citizens of a member state where he/she lives can start in the election only when they have the citizenship for a minimal period, it is regarded that EU citizens meet this requirement provided that they were citizens of one of Community states for the required minimal period. On the other hand, if citizens of a member state of the place of living have the right to vote or to start in the election only when they lived in the minimal period of living in the electoral area of this state, it is assumed that Community members eligible to vote and to start in elections meet this condition provided that the place of living period is the same as the minimal period of living in other member states. What is more, pursuant to Article 7 of the Act, member states are allowed to check if a particular EU citizen who expressed the will to vote in a particular country is not deprived of this right on the basis of regulations of the country of his/her origin. For this aim, a member state of the place of living can transfer the country of origin a statement supplied 
by a Community voter. What is more, a member state of the origin, in the proper term and proper way, shall provide essential and normally available information, however, it includes only such detailed data which are absolutely available to realise this project. One can use the obtained data for this aim. If the provided information discredit the statement content, a member state of the living place undertakes proper actions in order to undertake actions to prevent this person to start in election (Art. 7).

According to the Directive, to be able to use the right to vote in a member stay where he or she lives, a voter just needs to express such will. If a participation in the election in a member state where a voter lives is obligatory, he is obliged to take part in the election also in case when one expressed such will.

In order to enter the voters' list, he or she is obliged to submit the same documents which are required from voters having the citizenship of this particular member state. What is more, in order to be on the list of eligible voters, a voter should submit an official statement in which he or she states the citizenship, the address of a stay in a member state and in some cases also the election district or local community, on the list of which he or she was registered for the last time. In that document, a voter needs also to state that he or she shall use the voting right solely in the member state of his or her stay. That member state is allowed to ask a Voter to include in a statement that he/she has not been deprived of the voting right in the home country, as well as that the presented ID card is valid. Additionally, the member state is allowed to ask a Voter to state the date from which he or she stays in this or other member state. Community Voters remain at the voters' list until they submit an application of a removal from the list or till they are officially removed due to a failure of meeting the condition of using the voting right.

Similarly, however slightly different, is in case when a citizen of a member state expresses the will to start in the election in a member state of his/her stay, different of his nationality and citizenship. In the same way as in a will to vote in a member stay of one's stay, a voter who wants to start in the election is obliged to submit an official statement, which includes his/her citizenship and the address of a stay in the member state, to state that he/she is not starting in the EP election in another Community state and, when applicable, to indicate a voting district or local community in his/her home country, on the voters' list of which he/she was last registered. One difference is the obligation to submit a certificate acknowledging that a candidate was not deprived of passive voting right in that member state or that the authority is not informed about such fact. 
Such certificate is issued by a proper administrative authority of the candidate's home country (Art. 10 Par. 2).

A specific type of a limitation of active and passive voting rights was introduced in Art. 14 of the Directive. It concerns the case when in a particular Community state the percentage of EU citizens in the age allowing them to vote, which at the same time is their residence but they are not its citizens, is over $20 \%$ of the total number of EU citizens who live in this country. In the presented situation, such member state can introduce, by way of derogation, special requirements related with the period of residence. As far as the active voting right is concerned, it may grant the right to the voters eligible to vote, which have lived in this member state for a certain minimal period of time that cannot be longer than 5 years. In the case of starting in the elections, a Community voter can be eligible to start in the election if he/she has lived in this member state for a certain minimal period of time, which can be maximally set at 10 years. The discussed article was applicable to states which were Community members before 1995. The above mentioned right was used by Luxembourg, which introduced the requirement of 5 years of residence in order to obtain the active voting right (Grzelak 2004: 35).

In the case when a member state refuses to register one in the voters' list or rejects the application concerning a start in the election, one has the right to use proper legal means on the same rules as the legislation of this member state concerns voters and candidates that are this state's citizens. The Directive obliges Community states to inform voters in a proper form and in proper time about detailed conditions and rules of voting and standing in the election in this country. The above mentioned prohibition of multiple voting and starting in the election is to be guaranteed by common flow of information between Community state about entries on the electoral lists of voters and candidates who expressed such will in the country of residence. What is more, a home member state should implement proper means in order to prevent from the situation when its citizens vote or candidate during the same election in more than one Community state.

The above discussed Art. 10 Par. 2 of the Directive 93/109/EC, pursuant to provisions of the Council Directive 2013/1/EU of 20.12.2012 ${ }^{6}$, was amended. The

${ }^{6}$ Council Directive 2013/1/EU of 20.12.2012 amending the Directive 93/109/EC laying down detailed arrangements for the exercise of the right to vote and stand as a candidate in elections to the 
requirement specified in Art. 10 of the Directive 93/109/EC, that a Community citizen, when submits an application to stand as a candidate in a member state he is not a citizen of, submits the attestation from the competent administrative authorities of his home Member State certifying that he has not been deprived of the right to stand as a candidate in that Member State or that no such disqualification is known to those authorities, was removed. It was replaced by an official statement of such candidate, submitted at the moment of submitting an application to stand in the election, acknowledging that he or she was not deprived of the right to stand in the election to the EP in his/her country of origin. Due to the above, in the Art. 10 of the Directive 93/109/EC, Par. 2 was removed, being replace by point $\mathrm{d}$ ), stating that a candidate, when submitting an application, states that he was not deprived of the right to stand in the election in his country of origin by the power of a judicial decision or an administrative decision subject to an appeal. There was also introduced a requirement of informing the candidate's home member state by the member state of the candidate's residence about the above mentioned official statement in order to verify if that EU citizen was not actually deprived of the right to stand in the election to the EP in the state of his citizenship. After reception of such notice, the member state of the candidate's origin relays available proper information in any applicable way within 5 working days from the reception of the notice or, when possible, in a shorter period. Such information may include solely detailed data, which are indispensable to execute this obligation and can be used only for this aim. In case when the member state of the candidate's residence does not obtain the information in time, the candidate is allowed to stand in the election. However, when the obtained information turn out to discredit the content of the submitted statement, the state undertakes proper actions in accordance to its national legislation in order to disable this person stand in the election or, if it is not possible, to prevent an election of this person, or, in the case when he or she is elected, to prevent him/her from execution of the function. Such actions are executed regardless the fact if the member state of the candidate's residence obtained the information in the period of 5 days or not.

Pursuant to the provisions of the Council Directive 2013/1/EU, by 28.01.2014, the Community states were obliged to introduce legislative, executive and

European Parliament for citizens of the Union residing in a Member State of which they are not nationals, Journal of Laws L. 26 of 26.1.2013: 27. 
administrative regulations necessary for execution of the Directive. Member states immediately inform the Committee about that regulations?

\section{SUMMARY}

The European Union has not developed a uniform electoral law for the elections to the European Parliament. Despite defining the fundamental set of electoral rules in the Act on the election of European Parliament members in direct general election of 20.09.1976, there is still a large discrepancy in the election of MEPs. Despite the fact that since the very beginning of the existence of Communities the problem of lack of a uniform electoral law was the subject of works of various parliamentary committees, reports developed in the course of them did not contribute any new solutions, most of them copying the earlier proposed procedures. One chance for a constructive settlement of the above mentioned issue was the report proposed by a British liberal Andrew Duff, which was developed in October 2008. The primary aim of the report is empowerment of the European dimension of the election that the public eye and media engaged in political choices concerning the future of EU. As a result, a crucial role should be played by European political parties. Further part of the report indicates that the recognisability of the democratic role of the Parliament among the society is still limited. Political parties of the European rank are still at an early stage of development, election campaigns are more of a national than European character, and media coverage of the EU functioning is still irregular. The project's author was arguing that a change of the electoral system may have an influence on an increase of the attendance, an empowerment of the European scale of the election, making them more personal.

The Duff's report includes five main propositions of changing the existing electoral procedure. The first of them is an introduction of an obligatory division of states into voting districts when the number of citizens exceeds 20 million. The author proposed also the possibility of forming special districts to satisfy needs of linguistic minorities. The second proposal concerns a ranked voting

7 The Treaty of Lisbon amending the Treaty on European Union and the Treaty establishing the European Community, Journal of Laws EU 2007 C 306/1. Consolidated Treaty on European Union of 20.03.2010 was published in the Official Journal of the EU C 83/13, while the Treaty on functioning of the European Union in establishing the European in the Official Journal of the EU C 83/47. 
system, using half-open lists, along with the currently used Single Transferable Vote. Voting with a use of half-open lists is a situation when a voter selects candidates within the list. The third proposed solution is a novelty in the concepts of harmonising the electoral procedure. The project assumes an introduction of an additional so-called Union voting district. Due to that, it is proposed to increase the number of MEPs from 751 to 776. EP Members would be elected in national elections but from one Eurolist, common for the whole EU and one district covering the whole area of the Community. European political parties would appoint candidates, who would come from at least one third of member states and were selected in accordance to the equality of gender rules. Citizens of community member states would have the right to two votes, the first one for candidates or an individual candidate, depending on the electoral system of a particular state, and the second one for a preferred candidate from the EU list. The division of places would be conducted in accordance to Sainte-Laguës method. According to Duff, there should be election threshold for this district. This novelty would expand the selection range for voters and highlight the European scale of campaigns, at the same time leading to an enforcement of European political parties. Candidates would have the right to start both from the EU list as well as the national one. Candidates officially living in more than one member state and candidates with a dual citizenship would have the right to stand in the same election from more than one national or regional list.

A result of the above presented novelty would be an appointment of an electoral authority at the Community level. Its task would be a coordination of the election from the Eurolist. It would also set the upper limit of expenditures on election campaigns of parties and candidates. It would be formed by representatives of all member states, one from each state, and representatives of the Committee and the Parliament. The fourth proposal included in the Duff's report relates to the period of the election. It would take place only on Saturdays and Sundays, what, according to the author, would make it have a general European character. He proposed that the minimal age of being eligible to vote in the whole EU should be set at 16 and to stand in the election at 18 (Bachrynowski 2010: 61).

He also proposed a decrease of the number of days for the election from four to only two. The report was subject to a discussion during plenary sessions of the EP in the years 2009-2014. The main assumption of works of the Constitutional Committee was that the regulations entered into force as the community law already during 2014 election. The evaluation of the report is not 
explicit. Authors indicate positive aspects of presented proposals, focusing also on its disadvantages and difficulties which can be met at its implementation in the proposed form. The right of citizens of two votes and standing in elections in several member states at the same time would require an additional amendment of Directive 93/103/EC, which concerns detailed conditions of executing the right to vote and stand in election to the EP of EU citizens residing in a member state and not being its citizen. The Directive excludes the possibility of giving two votes in the same election and to candidate in more than one EU country (Gostyńska 2010: 4).

According to reviewers, an election of additional 25 MEPs from the European list and dividing seats between member states before each election can violate current balance in the institutional hierarchy in the EU and significantly increase the potential of the largest states at the cost of those smaller ones ${ }^{8}$.

Duff's report seems to be discussing the issue of harmonising the electoral procedure to the European Parliament in the most detailed way when compared to all reports presented so far. It is a subject of discussion until now due to a resistance of some member states to make such serious amendments in their electoral systems. As a result, it seems that a development of a uniform EP electoral procedure, common for all members, is still not possible. Member states, affectionate to their internal regulations, are not eager to introduce any changes in own electoral systems, what would be ineluctable at standardisation of the electoral procedure for the EP election.

\section{REFERENCES:}

Apostoł M. (1995). Parlament Europejski. Gliwice: Wokół Nas.

Bachrynowski S. (2010). Ujednolicenie ordynacji wyborczych do Parlamentu Europejskiego. „Państwo i Prawo” 3.

Barcz J. (2007). Przewodnik po Traktacie z Lizbony. Traktaty stanowiące Unię Europejska. Stan obecny oraz teksty skonsolidowane w brzmieniu Traktatu z Lizbony. „Europejski Przegląd Sądowy" 9.

Barcz J. (2009). Parlament Europejski w świetle postanowień Traktatu z Lizbony. [in:] Parlament Europejski po wyborach w 2009 roku. Nowe zadania w świetle Traktatu $z$ Lizbony. J. Barcz, B. Janusz-Pawletta (eds.). Warszawa: Instytut Wydawniczy EuroPrawo.

8 The report No. 35/2011 Brussels on April 20 $0^{\text {th }}, 2011$, Senate Chancellery, Office of the Senate representative to the European Union. 
Barcz J. (2010). Unia Europejska na rozstajach. Traktat z Lizbony: dynamika i główne kierunki reformy ustrojowej. Warszawa: Instytut Wydawniczy EuroPrawo.

Bardi L. (1990). The Harmonisation of European Electoral Law. [in:] Political Strategies and Electoral Reforms: Origins of Voting Systems in Europe in the 19 and 20 Centuries. S.I. Noiret (ed.). Baden-Baden: Nomos Verlagsgesellschaft.

Bartholdi J.J. (2003). Strategic Voting. Atlanta.

Bieber R. (1981). Conditions and Consequences of a Uniform Electoral Procedure for the European Parliament. [in:] The European Parliament: Towards a Uniform Procedure for Direct Elections. C. Sasse et al. (eds.). Florence-Luxembourg: European University Institute - Office for Official Publications of the European Communities.

Chałupa T. (2008). Problem jednolitej procedury wyborczej do Parlamentu Europejskiego. Kraków: Wyższa Szkoła Europejska im. Ks. Józefa Tischnera.

Chmaj M., Skrzydło W. (2011). System wyborczy w Rzeczypospolitej Polskiej. Warszawa: Wolters Kluwer.

Czachór Z. (1994). System europejskiej współpracy politycznej w integrowaniu Europy. Toruń: Wydawnictwo Adam Marszałek.

De Vries G. (1996). La procedure électorale uniforme du Parlement européen: un pas pour rapprocher l'Europe des citoyens. "Review Européennes" 399.

D. Dinan, (1993). Ever Closer Union, London.

Dyrektywa 93/109/WE z dnia 6 grudnia 1993 r., Dz.U. L 329, 30.12.1993.

Dyrektywa Rady 2013/1/UE z dnia 20 grudnia 2012 r. zmieniajacca dyrektywe 93/109/ WE $w$ odniesieniu do szczegółowych warunków wykonywania prawa kandydowania $w$ wyborach do Parlamentu Europejskiego przez obywateli Unii majacych miejsce zamieszkania w państwie członkowskim, którego nie sa obywatelami, Dz.U. L 26, 26.1.2013.

European Parliament Resolution of 10 October 1991 on the European Parliament's Guidelines for the Draft Uniform Electoral Procedure, http://www.ena.lu; [accessed 19.10.2015].

Europa-Verträge und Gesetze, (1972). Bonn.

Galster J. (1997). Pozycja Parlamentu Europejskiego w systemie instytucjonalnym Wspólnot Europejskich. Warszawa: PWN.

Galster J. (2008). Równowaga instytucjonalna jako kategoria doktrynalna, orzecznicza i normatywna. Studium zasady Unii Europejskiej. Toruń: Towarzystwo Naukowe Organizacji i Kierownictwa „Dom Organizatora”.

Galster J., Knade-Plaskacz A. (2010). Wpływ Traktatu z Lizbony na pozycję Parlamentu Europejskiego. „Przegląd Sejmowy” 5 (100).

Gebethner S., Urbaniak K. (2003). Przyszły polski system wyborczy do Parlamentu Europejskiego w świetle prawa wspólnotowego. „Przegląd Legislacyjny” 1 (35).

Gostyńska A. (2010). Reforma procedury wyborczej do Parlamentu Europejskiego. „Biuletyn” 113 (721).

Grzelak A. (2004). Wybory do Parlamentu Europejskiego w prawie Unii Europejskiej. [in:] Parlament Europejski. Wybrane zagadnienia. „Zeszyty Ośrodka Informacji i Dokumentacji Europejskiej” 4. 
Herma C. (2008). Reforma systemu aktów prawa pochodnego UE $w$ Traktacie z Lizbony. „Europejski Przegląd Sądowy” 5.

Huber P.M. (2003). Das institutionelle Gleichgewicht zwischen Rat Und Europäischem Parlament in der künftigen Verfassung für Europa, "Europarecht".

Introduction, Elections to the European Parliament: 10-11 \& 13 June 1999 Electoral Procedure, Electoral Law. [online] http://www.europarl.europa.eu/election/law/en/ lain01en.htm; [accessed 19.10.2015].

Jacobs F., Corbett R., Shackleton M. (1996). Parlament Europejski. Rzeszów: Wydawnictwo Wyższej Szkoły Pedagogicznej.

Kapteyn P.J.G, VerLoren van Themaat P. (1998). Introduction to the Law of the European Communities. London: The Hague.

Kenig-Witkowska M., Łazowski A., Ostrihansky R. (2006). Prawo instytucjonalne Unii Europejskiej. Warszawa: C.H. Beck.

Klepacki Z.M. (1967). Zachodnioeuropejskie zgromadzenia międzyparlamentarne. Studium porównawcze. Warszawa: Książka i Wiedza.

Konkluzje Rady Europejskiej. (2009). 11225/2/09 REV 2.

Kownacki T. (2004). Wybory do Parlamentu Europejskiego. [in:] Parlament Europejski w systemie instytucjonalnym Unii Europejskiej. Warszawa: Wydawnictwo Sejmowe.

Kruk M. (1997). Parlament Europejski: traktaty i praktyka. „Biuletyn Informacyjny Kancelarii Sejmu" 31.

Lenaerts K., van Nuffel P. (2005). Constitutional Law of the European Union. London.

Małuszyńska E., Gruchman B. (2010). Kompendium wiedzy o Unii Europejskiej. Warszawa: PWN.

Marszałek-Kawa J. (2002). Struktura i funkcjonowanie Parlamentu Europejskiego. Toruń: Wydawnictwo Adam Marszałek.

Marszałek-Kawa J. (2004). Parlament Europejski V kadencji (1999-2004) a parlamenty narodowe w państwach Unii Europejskiej (pozycja ustrojowa, kompetencje, organizacja wewnętrzna). Toruń: Wydawnictwo Adam Marszałek.

Mik C. (2000). Europejskie prawo wspólnotowe. Zagadnienia teorii i praktyki. Warszawa: PWN.

Millar D. (1990). A Uniform Electoral Procedure for European Elections. "Electoral Studies" 1.

Ostrihansky R. (1995). Parlament Europejski: struktura, zadania, procedury. Warszawa: Kancelaria Sejmu.

Polarczyk K. (2009). Wybory do Parlamentu Europejskiego. "Infos. Zagadnienia Społeczno-Gospodarcze" 9.

Postanowienie $z$ dnia 15 listopada 2007 r.w sprawie T-215/07 Donnici przeciwko Parlamentowi Europejskiemu, ECR 2007 II-1, pkt. 75.

Projekt sprawozdania: Andrew Duff. Wniosek dotyczacy zmiany Aktu dotyczacego wyborów przedstawicieli do Parlamentu Europejskiego w powszechnych wyborach bezpośrednich z dnia 20 września 1976 r. (2009). 2134. 
Rapport général de Fernand Dehousse, membre de l'Assemblée parlementaire européenne (30 avril 1960). (2009). [in:] Parlement européen. Direction générale de la documentation parlementaire et de l'information. Pour lélection du Parlement européen au suffrage universel direct. Luxembourg.

Sosnowski Ł. (2008). Nowy podział mandatów do Parlamentu Europejskiego. „Biuletyn Analiz UKIE" 20.

Toth A.G. (1991). The Oxford Encyclopedia of European Community Law. Oxford.

Traktat o Unii Europejskiej z Maastricht z dnia 7 lutego 1992 r. Dz.U. C 191, 29.7.1992.

Traktat o utworzeniu Europejskiej Wspólnoty Gospodarczej. Dz.U. 2004 Nr 90, poz. $864 / 2$.

Traktat z Amsterdamu z dnia 2 października 1997 r. Dz.U. C 340, 10.11.1997.

Traktat z Lizbony zmieniajacy Traktat o Unii Europejskiej i Traktat ustanawiajacy Wspólnotę Europejską. Dz.Urz. UE C 83/47.

Traktat o utworzeniu Europejskiej Wspólnoty Gospodarczej, z dnia 25 marca 1957 r., Dz. U. z 2004, Nr 90 poz. 864/2.

Westlake M. (1994). A Modern Guide to the European Parliament. London. 